\title{
The Optimal Condition for Peroxidase-Anti-Peroxidase Staining of Lung Tissues in Canine Dirofilariasis
}

Kouichi TANAKA* and R. B. ATWELL

Department of Veterinary Medicine, University of Queensland, St. Lucia, 4067, QLD, Australia

(Received 10 July 1989/Accepted 17 December 1989)

Jpn. J. Vet. Sci. 52(2): 447-451, 1990

KEY WORDS: canine lung, Dirofilaria immitis, immunoperoxidase (PAP) staining.

The previous studies have failed to identify immune complexes and immunoglobulin within pulmonary lesions of dogs infected with Dirofilaria immitis (Di) despite of the presence of Di antigen [5]. Only Abramowsky [1] incidentally observed deposits of IgM in one dog and IgG and $\mathrm{C}_{3}$ in another on the pulmonary arterial walls in his study for nephropathy using immunofluorescence staining. There have been a few reports of Di bodies in human tissue sections stained with peroxidase-anti-peroxidase staining (PAP) $[10$, 14]. However, PAP staining has not been investigated to detect Di in pulmonary tissue of a dog with dirofilariasis. So we attempted to get the optimal condition for the PAP method and to demonstrate the substances in dog tissue associated with $\mathrm{Di}$ by using either anti-fresh $\mathrm{Di}$ (anti-Di) serum, anti-IgG serum or anti-C $\mathrm{C}_{3}$ serum in the dog tissue.

Fresh adult female Di were collected at necropsy and washed in saline to obtain $\mathrm{Di}$ antigen. All steps were performed under $4^{\circ} \mathrm{C}$ and sterile conditions. For antigen preparation, chopped $\mathrm{Di}$ was disintegrated by ultra sonicater (BIOSONIK III, Bronwill Scientific, Rochesters N.Y.) 5 times for $2 \mathrm{~min}$ each at intensity 50 , in $1 \mathrm{mM}$ EDTA-8mM PBS saline ( $\mathrm{pH} 7.2$ ). The extract solution was centrifugated at $600 \times \mathrm{g}$ for $10 \mathrm{~min}$ to separate the sediment. The supernatant fluid was filtered through a $0.45 \mu \mathrm{m}$ filter. Protein was assayed according to the modified Lowry's procedure [6]. Adult male New Zealand rabbits (Central Animal Breeding House, University of Queensland) were immunized by injecting intramuscularly $1 \mathrm{mg}$ of protein in incomplete Freund's adjuvant every 14 days. Antibody responses were monitored by counter immunoelectrophoresis as described by Howe et al. [4].

*Correspondence to: TANAKa K., Exploratory Research Labs, Chugai Pharmaceutical Co., 1-135 Komakado Gotemba, Shizuoka 412, Japan.
Coagulated blood was sedimented by centrifuging at $750 \times \mathrm{g}$ for $20 \mathrm{~min}$ and serum was obtained. Normal rabbit serum was also obtained from one non-immunized rabbit by the same procedure. Anti-dog IgG serum and anti-dog $C_{3}$ serum were purchased from Cappel Worthington Biochemical. Five canine lung tissues infected naturally with Di (age, more than 4 years; detected Di number, 16-77) and 5 normal canine lung tissues as control were fixed with neutralized $10 \%$ formalin solution at the time of necropsy. Removed fresh $\mathrm{Di}$ worms were also fixed by neutralized $10 \%$ formalin. More than 2 days later, Di worms and lung tissues were embedded in paraffin, sliced at $4 \mu \mathrm{m}$, and fixed to slides with chrome alum-gelatin adhesive. The slides with tissues were kept overnight at $37^{\circ} \mathrm{C}$, held at $60^{\circ} \mathrm{C}$ for one hour, and routinely dewaxed. PAP staining was carried out according to Sternberger et al. $[8,9]$. The serum was incubated in a moist chamber at room temperature. Between steps, the tissue sections were washed in 3 changes of $0.05 \mathrm{M}$ Tris buffered saline solution ( $\mathrm{pH}$ 7.6: TBS) for $5 \mathrm{~min}$ each with gentle agitation on a magnetic stirrer.

Dilution rates for each reagent and serum and incubation times were modified as described to obtain satisfactory staining. To mask the nonspecific staining distributed on the tissues, whole swine serum was used. Since the lower dilution rate of whole swine serum was more effective than the higher dilution $[2,3,12,13,15]$, a dilution rate of 1:20 was selected. This was the thickest concentration that appeared in recommended references.

A blocking solution of $0.3,3.0$ or $30 \%$ hydrogen peroxide $\left(\mathrm{H}_{2} \mathrm{O}_{2}\right)$ solution was dropped onto the slides for $3,5,10,20$ or $30 \mathrm{~min}$. The $\mathrm{H}_{2} \mathrm{O}_{2}$ removed the endogenous peroxidase activity in the early PAP staining procedure. According to our results, $20-\mathrm{min}$ dropping of $3.0 \% \mathrm{H}_{2} \mathrm{O}_{2}$ solution effectively inhibited the endogenous cellular peroxidase activity in red cells and other tissue cells. Higher concentrations or longer incubation periods caused tissue damaged. 
As a primary serum, anti-Di serum (diluted with TBS 1:50, 1:100, 1:200, 1:300, 1:400, 1:500, $1: 800,1: 1000,1: 1200$ or $1: 1500$ and let stand 20 min, 2 or 21 hours), anti-IgG serum and anti- $C_{3}$ serum (each diluted with TBS 1:100, 1:300, $1: 600,1: 1000$ or $1: 1500$ and allowed to stand 20 min) were used. The optimal condition for each primary serum was determined according to the staining results. Staining for distinguishing $\mathrm{Di}$ from pulmonary tissue was obtained by 20 -min incubation and 1:300 dilution of anti-Di serum. The optimum anti-IgG serum and anti- $\mathrm{C}_{3}$ serum preparation was: dilution 1:1000 and incubation $20 \mathrm{~min}$.

Secondary serum (anti rabbit IgG goat serum, heavy and light chain specific; Cappel Worthington Biochemical) was diluted 1:200 in TBS and allowed to stand one hour. PAP complex serum (peroxidase anti-peroxidase complex rabbit serum; Cappel Worthington Biochemical) was diluted 1:400 in TBS and allowed to stand one hour.

A $50 \mathrm{mg}$ of 3,3-diaminobenzidine (DAB) was mixed in $100 \mathrm{~m} l$ of $0.05 \mathrm{M}$ TBS saline solution. The solution was filtered through media paper and $0.5 \mathrm{ml}$ of $30 \%$ of $\mathrm{H}_{2} \mathrm{O}_{2}$ was added. After used for different periods (45 sec, 1.5, 2, 3 or 5 min), the DAB solution was poured out of the bottle and distilled water was filled in the bottle. These steps should be handled in dim light. The results showed that $45 \mathrm{sec}$ exposure was best.

Thus, the optimal condition was determined by identifying the substances due to $\mathrm{Di}$ in tissue. The optimal dilution rates and incubate times for each reagent, serum and antiserum are summarized in Table 1. Routine counterstaining with Mayer's haematoxylin was performed for $5 \mathrm{~min}$ and washed with running water for $10 \mathrm{~min}$. The results are described in Table 2 .

Di excised from canine heart, adult Di, microfilariae (mf) and eggs in pulmonary tissue infected with Di were positively identified. They were colored brown using the anti-Di serum by the method established here. According to PAP using anti- $\mathrm{C}_{3}$, the surface of cuticle and intrauterine $\mathrm{mfs}$ and eggs showed faintly positive.

PAP using with anti-IgG serum showed no positive reaction to $\mathrm{Di}$ bodies. In pulmonary tissue, the circulating $\mathrm{mf}$, the adult Di body using anti-Di serum (Figs 1 and 2) and the IgG deposit using anti-IgG serum (Fig. 3), and the $\mathrm{C}_{3}$ deposit using anti- $\mathrm{C}_{3}$ serum (Fig. 4) were shown clearly. These results suggest that substances due to $\mathrm{Di}$ may be clearly demonstrated in the canine lung

Table 1. Summary of the optimal dilution rate and incubation period of the blocking solution and each antiserum and DAB solution in PAP staining

\begin{tabular}{|c|c|c|c|c|}
\hline \multirow[b]{2}{*}{ Stages } & \multirow[b]{2}{*}{$\begin{array}{l}\text { Time } \\
\text { (min.) }\end{array}$} & \multicolumn{3}{|c|}{ Objectives to stain } \\
\hline & & $\begin{array}{l}\text { Fresh } \\
\text { Di }\end{array}$ & $\begin{array}{l}\text { Dog } \\
\text { IgG }\end{array}$ & $\begin{array}{l}\text { Dog } \\
C_{3}\end{array}$ \\
\hline $\begin{array}{l}\text { Hydrogen } \\
\text { peroxide }\end{array}$ & 20 & \multicolumn{3}{|c|}{$\begin{array}{l}3.0 \% \text { hydrogen peroxide solution } \\
\text { for blocking peroxide activity }\end{array}$} \\
\hline $\begin{array}{l}\text { Nonspecific } \\
\text { whole serum }\end{array}$ & 40 & $\begin{array}{l}\text { 1: } 20 \\
\text { (swine) }\end{array}$ & $\begin{array}{l}\text { 1: } 20 \\
\text { (swine) }\end{array}$ & $\begin{array}{l}\text { 1: } 20 \\
\text { (swine) }\end{array}$ \\
\hline $\begin{array}{l}\text { Primary } \\
\text { antiserum }\end{array}$ & 20 & $\begin{array}{l}\text { 1: } 300 \\
\text { anti-Di } \\
\text { (rabbit) }\end{array}$ & $\begin{array}{l}\text { 1: } 1000 \\
\text { anti-IgG } \\
\text { (rabbit) }\end{array}$ & $\begin{array}{l}\text { 1: } 1000 \\
\text { anti-C } \\
\text { (goat) }\end{array}$ \\
\hline $\begin{array}{l}\text { Secondary } \\
\text { antiserum }\end{array}$ & 60 & $\begin{array}{l}\text { 1: } 200 \\
\text { (goat) }\end{array}$ & $\begin{array}{l}\text { 1: } 200 \\
\text { (goat) }\end{array}$ & $\begin{array}{l}\text { 1: } 200 \\
\text { (rabbit) }\end{array}$ \\
\hline $\begin{array}{l}\text { PAP complex } \\
\text { serum }\end{array}$ & 60 & $\begin{array}{l}\text { 1: } 400 \\
\text { (rabbit) }\end{array}$ & $\begin{array}{l}\text { 1: } 400 \\
\text { (rabbit) }\end{array}$ & $\begin{array}{l}\text { 1: } 400 \\
\text { (goat) }\end{array}$ \\
\hline $\begin{array}{l}\text { DAB } \\
\text { solution }\end{array}$ & $\begin{array}{l}0.75 \\
-2\end{array}$ & \multicolumn{3}{|c|}{$\begin{array}{l}0.05 \% \mathrm{DAB}+0.15 \% \text { hydrogen peroxide } \\
\text { for pigmented }\end{array}$} \\
\hline
\end{tabular}

( ) shows the animals from which serum was obtained. 
Table 2. Observation of substances concerned with Di worms under PAP staining

\begin{tabular}{llllll}
\hline & \multicolumn{5}{c}{ Primary serum } \\
\cline { 2 - 6 } Sample & object & $\begin{array}{c}\text { normal } \\
\text { serum }\end{array}$ & $\begin{array}{c}\text { anti- } \\
\text { Di }\end{array}$ & $\begin{array}{c}\text { anti- } \\
\text { IgG }\end{array}$ & C $_{3}$ \\
\hline Live male & body & - & + & - & +- \\
adult worm & sperm & - & + & - & - \\
\hline Live female & body & - & + & - & +- \\
adult worm & egg(a) & - & + & - & +- \\
& mf(a) & - & + & - & +- \\
\hline \multirow{5}{*}{ Lung } & body & - & + & - & +- \\
& egg(a) & - & + & - & - \\
tissue & egg(b) & - & + & - & - \\
& mf(a) & - & + & - & - \\
& mf(b) & - & + & - & - \\
& IgG deposit & - & - & + & - \\
& $\mathrm{C}_{3}$ deposit & - & - & - & + \\
& tissue & - & - & - & - \\
\hline
\end{tabular}

mf: microfilariae, (a): intra-uterine, (b): circulating, - : negative stain, + : positive stain, +- : faintly positive.

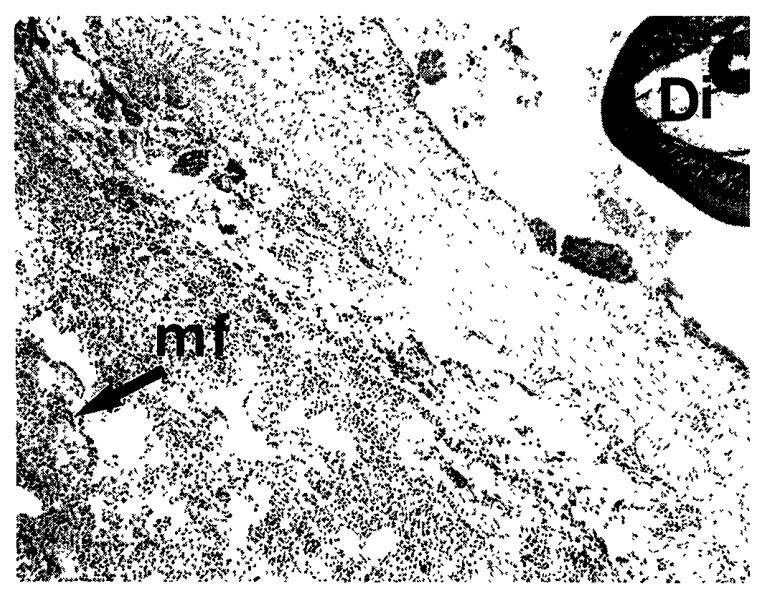

Fig. 1. PAP stained with anti-Di serum. Adult Di and $\mathrm{mf}$ (arrow) were positively stained in the same tissue. $\times 40$.

tissue.

It has been believed that the determination of the optimal condition for PAP staining technology was complicated owing to interactions among procedures. The exposure condition of anti-Di serum was initially referred from previous articles $[2,3,8,9,10,12,13,15]$ and Di worms, as well as the background of pulmonary tissues, were stained too heavily. In order to find out the reason, the incubation steps were checked, with reveals that the power (dilution rate $\times$ incubation time) of the exposure by the primary serum

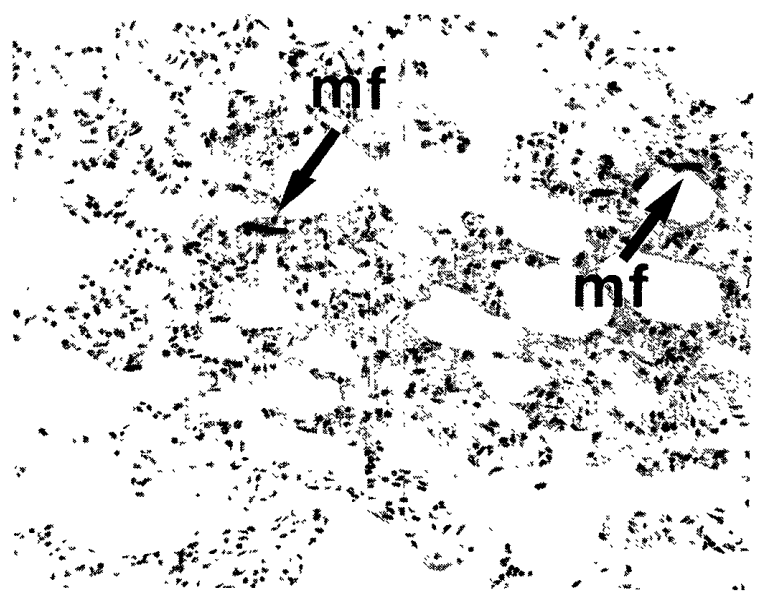

Fig. 2. PAP stained with anti-Di serum. Mfs (arrows) appear on the surface of alveolar walls. $\times 200$.

was too strong. The incubation period longer than overnight has been reported in almost half the articles $[3,7,9,13]$. Others Shave recommended that between 20 to $30 \mathrm{~min}$. The recent article has recommended that 60 hours at $4^{\circ} \mathrm{C}$ for primary serum incubation [7]. Finally, we settled on 20 min-incubation period for suitable results.

In contrast, the selection of dilution rates for anti-IgG serum and anti- $\mathrm{C}_{3}$ serum were easier than that for anti-Di serum because the deciding variable for these sera was only the dilution rate. The optimal dilution rate selected was 1:1000. 


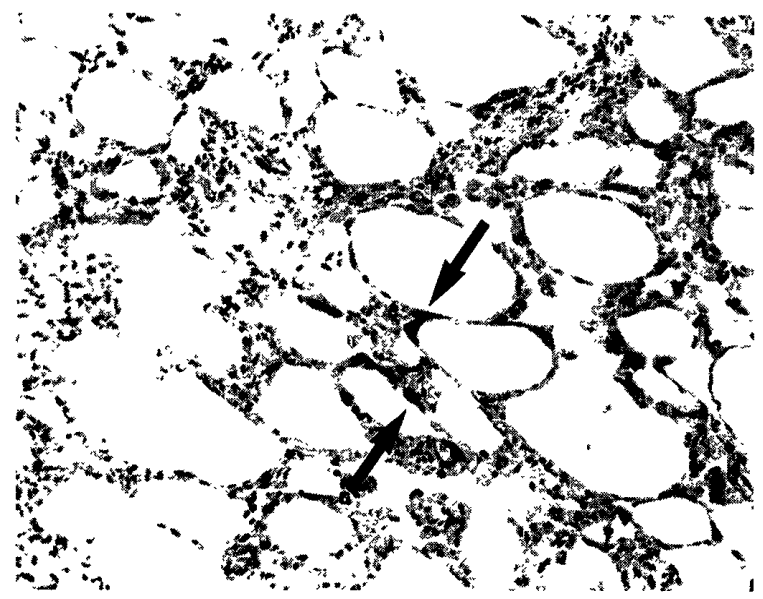

Fig. 3. PAP stained with anti-IgG serum. IgG deposits (arrows) are shown on the alveolar walls. $\times 400$.

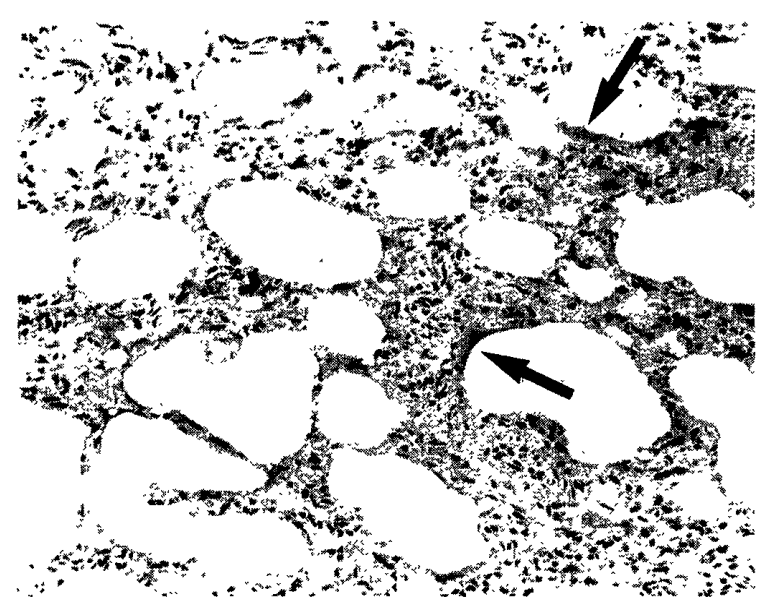

Fig. 4. PAP stained with anti- $\mathrm{C}_{3}$ serum. $\mathrm{C}_{3}$ are shown (arrows) on the surface of alveolar walls. $\times 400$.

With respect to the incubation time of the $\mathrm{DAB}$ solution, the 5-min incubation recommended by almost half the previous references caused too heavy staining, even if the surface of the slide glass was stained. Under the optimal condition above, the slides should be monitored in an incubation bottle until colored moderately. In conclusion, experiments were planned to find good staining conditions by varying dilution rates and incubation times for the peroxidase blocking solution, primary antisera, secondary antiserum, PAP complex antiserum, and chromogen solution. By microscopic observation, substances due to Di were positively identified and were colored brown in the Di-infected pulmonary tissue using
anti-Di serum, anti-IgG serum and/or anti- $\mathrm{C}_{3}$ serum. These results showed that immunologic substances related to Di infection were definitely demonstrated in the pulmonary tissue with canine dirofilariasis.

\section{REFERENCES}

1. Abramowsky, C. R., Powers, K. G., Aikawa, M., and Swinehart, G. 1981. Am. J. Pathol. 104: 1-12.

2. Bourne, J. A. 1983. Handbook of immunoperoxidase staining methods. Bulletin published by DAKO Corporation.

3. Burns, J. 1982. The unlabelled antibody peroxidase-anti-peroxidase method (PAP). pp. 91-105. In: Techniques in immunocytochemistry (Bullock, G. R. and Petrusz, P. eds.), Academic Press, London.

4. Howe, C., Lee, L. T., Harboe, A., and Haukenes, G. 1967. J. Immunol. 98: 543-557.

5. Knight, D. H. 1983. Heartworm disease. pp. 1097-1124. In: Textbook of veterinary internal medicine, vol. 1, 2nd ed. (Ettinger, S. J. ed.), W. B. Saunders Co. Phiradelphia.

6. Markwell, M. A. K., Haas, S. M., Bieber, L. L., and Tolbert, N. E. 1978. Anal. Biochem. 87: 206-210.

7. Palmer, D. G. 1986. Annual Conference Proceedings of Australian Society for Veterinary Pathlogy, 1.3.1.

8. Sternberger, L. A., Hardy, P. H. Jr., Cuculis, L. L., and Meyer, H. G. 1970. J. Histochem. Cytochem. 18: 315-333.

9. Sternberger, L. A. 1979. The unlabelled antibody peroxidase-antiperoxidase (PAP) method. pp. 104-169. In: Immuocytochemistry, 2nd ed. John Wiley and Sons, New York.

10. Suzuki, T. and Ono, I. 1981. Jpn. J. Parasitol. 30: 509-516.

11. Suzuki, T., Aoki, N., and Yamashita, T. 1981. Jpn. J. Parasitol. 30: 517-526.

12. Taylor, C. R. 1978. Arch. Pahtol. Lab. Med. 102: 113-121.

13. Vandesande, F. 1983. Peroxidase-antiperoxidase techniques. pp. 101-109. In: Immunohistochemistry (Cuello, A. C. ed.), John Wiley and Sons, Chichester.

14. Weil, G. J., Malane, M. S., Power, K. G., and Blair, L. S. 1985. J. Immunol. 134: 1185-1191.

15. Wordinger, R. J., Miller, G. W., and Nicodemus, D. S. 1983. Immunoperoxidase methods. pp. 51-57. In: Manual of immunoperoxidase techniques, American Society of Clincial Pathologists Press, Chicago. 
要 約

犬系状虫症に扔ける肺組織に対するPAP 染色の至適条件 (短報)：田中公一・R. B. Atwell(クィーンズランド 大学獣医学部) 一一大系状虫 $(\mathrm{Di})$ 自然感染犬 5 例㧍よび非感染犬 5 例を用いて, 酵素抗体染色法 $(\mathrm{PAP})$ の染色条 件を検討した。 至適条件は $3 \% \mathrm{H}_{2} \mathrm{O}_{2}$ 水 (20分), 20 倍希釈豚血清 (40分), 一次抗体 (300倍希秎抗 Di 血清, 1000 倍希釈抗犬 IgG 血清あるいは1000倍希釈抗犬 $\mathrm{C}_{3}$ 血清のうち一種を20分), 二次抗体 (60分), PAP 抗体 (60分) お よび $0.05 \% \mathrm{DAB}$ (45秒)を順次反応させる条件とした，その結果，感染犬の肺組織中に免疫関連物質，即ち抗原 (成熟 $\mathrm{Di}$, ミクロフィラリア，卵)・抗体 $(\mathrm{IgG}) ・$ 補体 $\left(\mathrm{C}_{3}\right)$ を明確に認めることができた. 